Article

\title{
Comparative Time-Course Study of Aminoacyl- and Dipeptidyl-Resin Hydrolysis
}

\author{
Guita N. Jubilut ${ }^{a}$, Reinaldo Marchetto ${ }^{b}$, Eduardo M. Cilli $^{a}$, Eliandre \\ Oliveira $^{a}$, Antonio Miranda ${ }^{a}$, Mineko Tominaga ${ }^{a}$, and Clóvis R. Nakaie $e^{*}$ \\ ${ }^{a}$ Departamento de Biofísica, Universidade Federal de São Paulo, Rua 3 de Maio 100, \\ 04044-020 São Paulo - SP, Brazil \\ ${ }^{b}$ Departamento de Bioquímica, Instituto de Química, Universidade Estadual Paulista \\ 14800-060 Araraquara - SP, Brazil
}

Received: April 26, 1996; August 12, 1996

\begin{abstract}
O método clássico de hidrólise para a quantificação de grupamentos aminoacílicos e peptídicos ligados a resinas em $\mathrm{HCl} 12 \mathrm{~N}$ : ácido propiônico foi reavaliada, estudando-se a influência da natureza da resina e do grupamento ligado à mesma. A estabilidade frente à hidrólise ácida foi dependente do amino acido C-terminal e a ordem de estabilidade ácida foi Phe $>$ Val $>$ Gly. Por outro lado, os dipeptídeos Ala-Gly, Ala-Val e Ala-Phe apresentaram maiores velocidades de hidrólise da resina, se comparadas com a dos correspondentes grupos aminoacílicos. Dentre as resinas testadas, a ordem de estabilidade foi: benzidrilamino-resina>p-metilbenzidrilamino-resina $\cong 4$-(oximetil)-fenilacetamidometil-resina > copolímero de estireno clorometilado, contendo $1 \%$ de divinilbenzeno. Importante para a metodologia de síntese de peptídeos, os resultados demonstraram que tempos de hidrólise mais longos do que os propostos há anos na literatura $\left(1 \mathrm{~h} \mathrm{a} 130^{\circ} \mathrm{C} \mathrm{e} 15 \mathrm{~min}\right.$ a $160{ }^{\circ} \mathrm{C}$ para os peptídeos ligados ao copolímero de estireno clorometilado, contendo $1 \%$ de divinilbenzeno), são necessários para uma clivagem quantitativa de alguns grupos ligados à resina. A ampla faixa de tempos de hidrólise observada variou de menos de $1 \mathrm{~h}$ até cerca de $100 \mathrm{~h}$.
\end{abstract}

The classic hydrolysis procedure for quantification of resin-bound aminoacyl and peptidyl groups with $12 \mathrm{~N} \mathrm{HCl}$ : propionic acid was reevaluated by studying the influence of the nature of the resin and the resin-bound group. Their stability during acid hydrolysis was dependent on the C-terminal amino acid, and the order of acid stability was Phe $>$ Val $>$ Gly. Otherwise, the dipeptides Ala-Gly, Ala-Val, and Ala-Phe displayed enhanced rates of hydrolysis of the resin if compared with their parent aminoacyl groups. Amongthe resins assayed, the order of acid stability was:

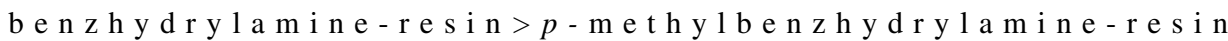
$\cong 4$-(oxymethyl)-phenylacetamidomethyl-resin > chloromethyl-copolymer of styrene-1\%-divinylbenzene. Important for peptide synthesis method, the findings demonstrate that longer hydrolysis times than previously recommended in the literature $\left(1 \mathrm{~h}\right.$ at $130{ }^{\circ} \mathrm{C}$ and $15 \mathrm{~min}$ at $160{ }^{\circ} \mathrm{C}$ for peptides attached to the chloromethyl-copolymer of styrene-1\%-divinylbenzene) are necessary for the quantitative acid-catalyzed cleavage of some resin-bound groups. The observed broad range of hydrolysis time varied from less than $1 \mathrm{~h}$ to about $100 \mathrm{~h}$.

Keywords: peptide hydrolysis, resin, acid hydrolysis, amino acid analysis, acyl-resin hydrolysis, solid phase peptide synthesis

\section{Introduction}

In solid phase peptide synthesis method ${ }^{1-4}$, the resin-bound amino acid or peptide content is usually deter- mined through acid hydrolysis of the composite resin, followed by amino acid analysis. However, since the incep- 
tion of the propionic acid-12 $\mathrm{N} \mathrm{HCl}$ solution $(1: 1, \mathrm{v} / \mathrm{v})$ as the standard hydrolysis protocol $^{5-7}$, no additional systematic studies have been carried out on the applicability of this procedure to other resins introduced later in the peptide synthesis technique. Moreover, the exact role of other factors in this cleavage reaction, such as the nature and the loading of the aminoacyl or peptidyl groups bound to the resin matrix, has not yet been thorougly investigated.

The goal of the present report is to investigate the influence of these factors and to propose an appropriate hydrolysis procedure for each class of resin-bound group. Among the resins studied, this paper will focus on those employed in the Boc- $\alpha$ amino group protecting the synthesis strategy ${ }^{1,2}$, i.e., the classic chloromethyl-copolymer of styrene $1 \%$ divinylbenzene (CMSD) and the 4-(oxymethyl)-phenylacetamidomethyl-resin $(\mathrm{PAMR})^{8}$ employed for the synthesis of C-terminal free $\alpha$-carboxyl peptides, and the benzhydrylamine-resin (BHAR) ${ }^{9}$ and the $p$-methylbenzhydrylamine-resin (MBHAR) ${ }^{10}$ used alternatively for assembling $\alpha$-carboxamide sequences. To avoid the risk of acid degradation which could hamper the present quantitative time-course hydrolysis study, the acid-stable amino acids Gly, Val and Phe were chosen as the resin-bound residues. The corresponding resin-bound alanyl sequences (Ala-Gly, Ala-Val, and Ala-Phe) were se- lected not only as models of peptide resins, but also to evaluate the influence of the $\alpha$-amino group acylation of the $\mathrm{C}$-terminal residue on their rate of acid cleavage from the resin.

\section{Materials and Methods}

The tert-butyloxycarbonyl (Boc)-amino acids (Gly, Val, Phe, and Ala) were purchased from Bachem, California. The aminoacyl-resins were acquired from the following companies: MBHAR, Sigma; PAMR, Bachem California, and CMSD, Bachem California and Calbiochem-Novabiochem. BHAR was either synthesized in the laboratory or purchased from Watanabe or Bachem California. Unless otherwise stated, the amino acid loading of resins ranged from about 0.3 to $0.6 \mathrm{mmol} / \mathrm{g}$. Solvents and reagents were of analytical grade and purchased from Aldrich or Fluka.

Amino-acyl- or peptidyl-resins were manually synthesized using the solid phase method ${ }^{1,2}$, and the ninhydrin assay ${ }^{11}$ was used to check the effectiveness of the coupling reactions. The Boc- $\mathrm{N}^{\alpha}$-protecting group was removed by trifluoroacetic acid treatment $(30 \% \mathrm{v} / \mathrm{v}$, in dichloromethane for $30 \mathrm{~min}$ ) prior to the acid cleavage study. Hydrolyses of resins were done with propionic acid: $12 \mathrm{~N} \mathrm{HCl}$ $\left(1: 1, \mathrm{v} / \mathrm{v}\right.$ at $130^{\circ} \mathrm{C}$ or $\left.160{ }^{\circ} \mathrm{C}\right)$ in Pyrex tubes with plastic
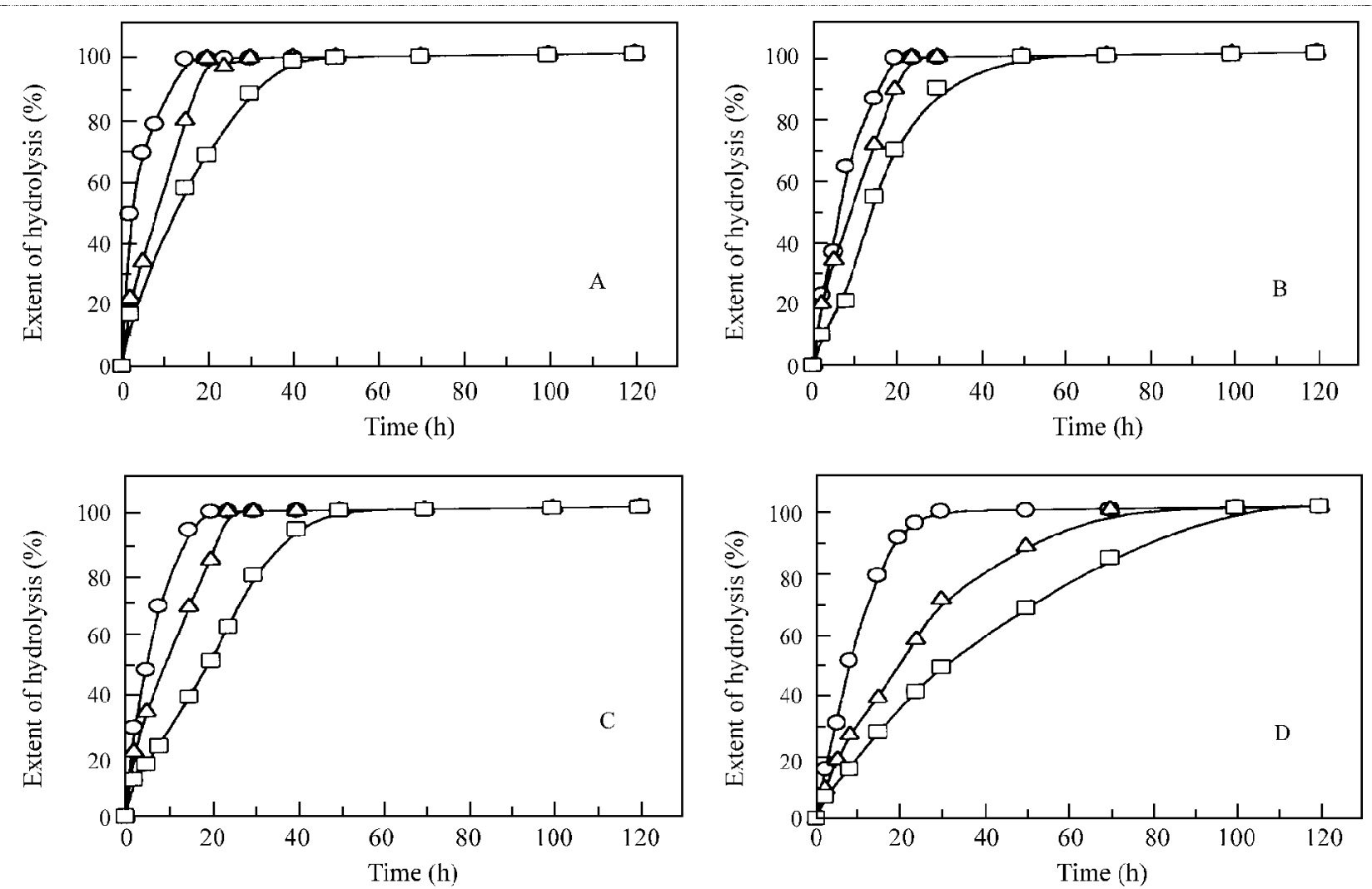

Figure 1. The time course of aminoacyl-resin hydrolysis at $130^{\circ} \mathrm{C}$ in propionic acid:12 $\mathrm{N} \mathrm{HCl} \mathrm{(1:1,} \mathrm{v/v).} \mathrm{Resins:} \mathrm{(A)} \mathrm{CMSD,} \mathrm{(B)} \mathrm{PAMR,(C)}$ MBHAR, and (D) BHAR. Amino acids: (O) Gly, ( $\Delta$ ) Val, and ( $\square$ ) Phe. 
teflon-coated screw caps $(13 \mathrm{~cm} \times 1 \mathrm{~cm})$, and amino acid analyses were performed in a Beckman 6300 amino acid analyzer system.

\section{Results and Discussion}

\section{Hydrolysis of aminoacyl-resins}

Figure 1 displays the time course of the hydrolysis of the four aminoacyl-resins at $130^{\circ} \mathrm{C}$. As expected, regardless of the resin, the small polar Gly residue was much more labile than Val or Phe, in accordance with the well-known higher acid stability of resin-bound hydrophobic residues ${ }^{12}$. As previously discussed ${ }^{13}$, the higher stability of Phe compared to the Val residue may be due to the electron withdrawing effect of its benzene ring at the resin linkage, resulting in a higher resistance to acidolytic cleavage.

The nature of the polymeric support also affected the rate of hydrolysis, irrespective of the resin-bound amino acid. The decreasing order of resin-bound acid stability was: BHAR $>$ MBHAR $=$ PAMR $>$ CMSD $($ Fig. 1 ). To the best of our knowledge, there are no previous reports on such a comparative study of the hydrolysis of these resins which are widely employed for peptide synthesis. The lower acid stability of CMSD as compared to PAMR, and of MBHAR as compared to BHAR, has already been demonstrated based upon trifluoroacetic ${ }^{14}$ and hydrogen fluoride ${ }^{10}$ treatments,
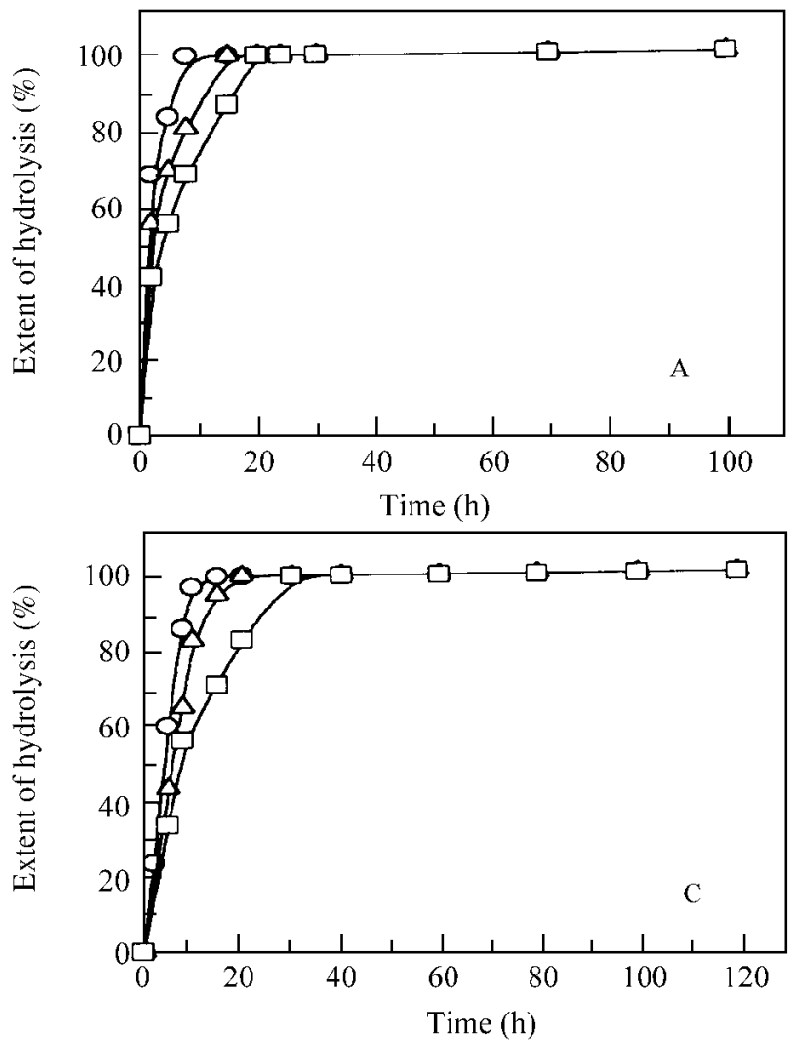

Figure 2. The time course of dipeptidyl-resin hydrolysis at $130{ }^{\circ} \mathrm{C}$ in propionic acid:12 $\mathrm{N} \mathrm{HCl}(1: 1, \mathrm{v} / \mathrm{v})$. Resins: (A) CMSD, (B) PAMR, (C) MBHAR, and (D) BHAR. Peptides: (O) Ala-Gly, $(\Delta)$ Ala-Val, and ( $\square$ ) Ala-Phe. respectively. The findings confirmed the very high acid stability of $\mathrm{BHAR}^{9,10,15}$, and also revealed rather similar acid stability properties of the PAMR and MBHAR polymers.

The results suggest that the reaction times recommended in the literature for the hydrolysis procedure, i.e., $2 \mathrm{~h}$ with the CMSD resin ${ }^{5-7}$ or $18 \mathrm{~h}$ with the MBHAR/ BHAR resins ${ }^{10}$ at $130^{\circ} \mathrm{C}$, are not adequate to achieve quantitative removal of resin-linked amino acids. The time required for the complete cleavage of resin-bound amino acids varied from a minimum of approximately $15 \mathrm{~h}$ with the most labile Gly-CMSD to a maximum of $100 \mathrm{~h}$ with the very stable Phe-BHAR. aminoacyl- or peptidyl-containing resins used in the present report were also different regarding their loading degree or their commercial source. To determine whether the degree of resin loading affected the hydrolysis results, the hydrolysis data of three Phe-BHAR batches containing 0.44, 0.91, and $1.54 \mathrm{mmol} / \mathrm{g}$ of Phe were compared. The two latter samples were obtained from highly amino group-loaded BHAR batches synthesized according to a forceful synthetic proto$\mathrm{col}^{16}$. No significant differences in the acid stability properties of the three resins were detected (data not shown). A possible influence of the source of resins on their hydrolysis behavior was also ruled out, since the two commercial Phe-BHAR batches (purchased from Bachem California
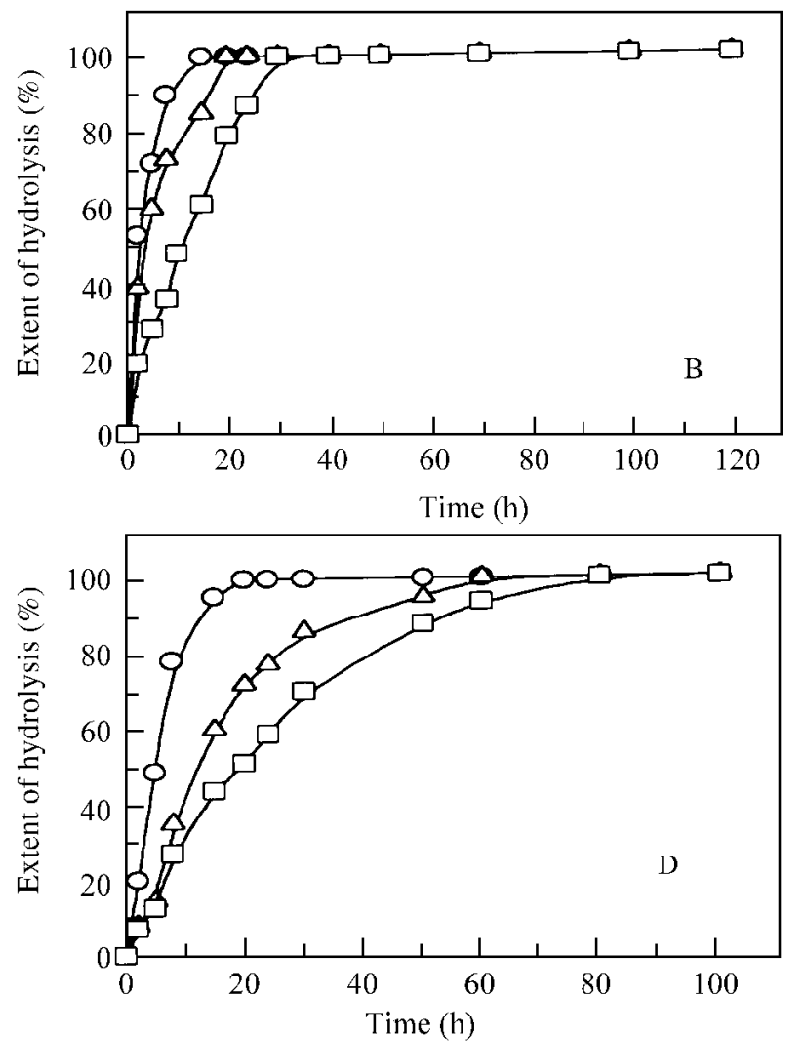

As detailed in the Material and Methods section, the 
and Watanabe) showed similar hydrolysis kinetics when compared to the above-described samples of laboratory-synthesized BHAR. Also, no difference was observed between the Val-CMSD batches from different companies (Bachem California and Calbiochem-Novabiochem, data not shown).

Alternative procedures using temperatures higher than $130{ }^{\circ} \mathrm{C}$ have been previously introduced ${ }^{7}$ to accelerate the hydrolysis reaction. Table 1 presents the time-course data of the hydrolysis of Gly-, Val-, and Phe-resins obtained at 160 ${ }^{\circ} \mathrm{C}$. As expected, hydrolyses faster than those at $130{ }^{\circ} \mathrm{C}$ were observed, but the reaction time necessary to quantitatively cleave the aminoacyl groups ranged from about $4 \mathrm{~h}$ (Gly-CMSD) to about $30 \mathrm{~h}$ (Phe-BHAR), longer than that recommended in the literature for $160{ }^{\circ} \mathrm{C}^{7}$.

\section{The hydrolysis of dipeptidyl-resins}

The mechanism of the acid hydrolysis of an aminoacyl group bound to the resin matrix irrespective of the nature of the linkage (ester or amide in the case of CMSD/ PAMR or MBHAR / BHAR resins, respectively) is possibly influenced by the free or acylated form of its $\alpha$-amino group. Thus, to compare with the Gly-, Val-, and Phe-resins, the corresponding dipeptidyl Ala-Gly-, Ala-Val- and Ala-Phe-containing resins were synthesized and studied as to their stability in acid hydrolysis. To avoid the influence of other factors, the same N-terminal acylation group (alanine) was deliberately employed in this comparative study.

Figure 2 shows the results of the hydrolysis experiments with peptidyl-resins at $130{ }^{\circ} \mathrm{C}$. Faster hydrolyses were observed with the peptidyl-resins when compared with the parent aminoacyl-resins (Fig. 1). For instance, the hydrolysis time necessary for the total cleavage of the Gly residue from the resin decreased from about $15 \mathrm{~h}$ for Gly-CMSD (Fig.
1A) to about $10 \mathrm{~h}$ for Ala-Gly-CMSD (Fig. 2A). In the case of Phe-containing resins, the same trend was observed and ranged from about $100 \mathrm{~h}$ (Phe-BHAR, Fig. 1D) to $70 \mathrm{~h}$ (Ala-Phe-BHAR, Fig. 2D). These findings indicate that the acylation of the $\alpha$-amino group of the resin-bound amino acid facilitates its hydrolytic removal from the resin.

Concerning the influence of the type of amino acid or resin, the decreasing order of acid stability for peptidyl-resins paralleled that observed for aminoacyl-resins, being: Ala-Phe $>$ Ala-Val $>$ Ala-Gly and $\mathrm{BHAR}>\mathrm{MBHAR}=\mathrm{PAMR}>\mathrm{CMSD}$.

As expected, under a more severe condition $\left(160^{\circ} \mathrm{C}\right)$, the minimum and maximum hydrolysis times necessary to achieve complete peptidyl cleavage varied from less than $1 \mathrm{~h}$ to about $25 \mathrm{~h}$ for the labile Ala-Gly-CMSD and the more stable Ala-Phe-BHAR, respectively (Table 2).

Moreover, the present time-course study also allowed the evaluation of the hydrolysis time necessary for the complete cleavage of the peptide bond between the alanyl residue and Gly, Val, or Phe residues bound to the resin. The results indicate that hydrolysis times of about $2 \mathrm{~h}\left(\right.$ at $130{ }^{\circ} \mathrm{C}$ ) and about $45 \mathrm{~min}$ (at $160{ }^{\circ} \mathrm{C}$ ) are sufficient for the quantitative cleavage of these peptide bonds. As these hydrolysis times are shorter than those necessary for quantitatively cleaving any resin-bound $\mathrm{C}$-terminal amino acids under the same conditions (see Figs. 1 and 2 and Tables 1 and 2), the Ala/Gly, Ala/Val, and Ala/Phe molar ratios found in amino acid analyses of dipeptidyl-resin hydrolyzates are usually higher than 1 .

Table 3 summarizes the results of this study showing the approximate reaction times necessary to quantitatively cleave the resin-bound $\mathrm{C}$-terminal amino acid when alone or in a peptide sequence at $130^{\circ} \mathrm{C}$ and at $160{ }^{\circ} \mathrm{C}$. As indicated, this reaction time is strongly dependent on the nature of the

Table 1. The extent of the hydrolysis (\%) of aminoacyl-resins in propionic acid:12 $\mathrm{N} \mathrm{HCl}(1: 1, \mathrm{v} / \mathrm{v})$ at $160{ }^{\circ} \mathrm{C}$.

\begin{tabular}{|c|c|c|c|c|c|c|c|c|c|c|c|}
\hline \multirow{2}{*}{$\begin{array}{l}\text { Amino } \\
\text { Acyl-Resins }\end{array}$} & \multicolumn{11}{|c|}{ Time (h) } \\
\hline & 2 & 3 & 4 & 5 & 8 & 10 & 15 & 18 & 20 & 24 & 30 \\
\hline Gly-CMSD & 76 & 86 & 90 & 97 & 100 & - & - & - & - & - & - \\
\hline Val-CMSD & 59 & 71 & 80 & 85 & 90 & 97 & 100 & - & - & - & - \\
\hline Phe-CMSD & 50 & 61 & 74 & 80 & 86 & 92 & 99 & 100 & - & - & - \\
\hline Gly-PAMR & 65 & 79 & 86 & 93 & 97 & 100 & - & - & - & - & - \\
\hline Val-PAMR & 51 & 60 & 71 & 81 & 89 & 95 & 100 & - & - & - & - \\
\hline Phe-PAMR & 47 & 55 & 67 & 76 & 84 & 90 & 95 & 100 & - & - & - \\
\hline Gly-MBHAR & 63 & 76 & 84 & 90 & 94 & 100 & - & - & - & - & - \\
\hline Val-MBHAR & 49 & 58 & 70 & 79 & 86 & 93 & 99 & 100 & - & - & - \\
\hline Phe-MBHAR & 41 & 54 & 66 & 74 & 81 & 90 & 95 & 100 & - & - & - \\
\hline Gly-BHAR & 25 & - & - & 78 & 88 & 93 & 100 & - & - & - & - \\
\hline Val-BHAR & 12 & - & - & 35 & 47 & 53 & 68 & 76 & 89 & 97 & 100 \\
\hline Phe-BHAR & 10 & - & - & 31 & 40 & 49 & 58 & 69 & 75 & 88 & 99 \\
\hline
\end{tabular}


Table 2. The extent of the hydrolysis (\%) of dipeptidyl-resins in propionic acid:12 N $\mathrm{HCl}(1: 1, \mathrm{v} / \mathrm{v})$ at $160{ }^{\circ} \mathrm{C}$

\begin{tabular}{|c|c|c|c|c|c|c|c|c|c|c|c|c|c|}
\hline \multirow[t]{2}{*}{ Peptidyl-Resin } & \multicolumn{13}{|c|}{ Time (h) } \\
\hline & 0.25 & 0.5 & 1 & 2 & 3 & 4 & 5 & 8 & 10 & 15 & 18 & 20 & 24 \\
\hline Ala-Gly-CMSD & 82 & 100 & - & - & - & - & - & - & - & - & - & - & - \\
\hline Ala-Val-CMSD & 11 & - & 30 & 84 & 91 & 99 & 100 & - & - & - & - & - & - \\
\hline Ala-Phe-CMSD & - & - & 26 & 79 & 86 & 92 & 97 & 100 & - & - & - & - & - \\
\hline Ala-Gly-PAMR & - & 40 & 67 & 84 & 95 & 100 & - & - & - & - & - & - & - \\
\hline Ala-Val-PAMR & - & - & - & 42 & 63 & 88 & 94 & 100 & - & - & - & - & - \\
\hline Ala-Phe-PAMR & - & - & - & 35 & 58 & 79 & 89 & 95 & 100 & - & - & - & - \\
\hline Ala-Gly-MBHAR & - & - & - & 81 & 93 & 100 & - & - & - & - & - & - & - \\
\hline Ala-Val-MBHAR & - & - & - & 39 & 58 & 85 & 93 & 99 & 100 & - & - & - & - \\
\hline Ala-Phe-MBHAR & - & - & - & 31 & 53 & 77 & 86 & 91 & 97 & 100 & - & - & - \\
\hline Ala-Gly-BHAR & - & - & - & 68 & 85 & 93 & 100 & - & - & - & - & - & - \\
\hline Ala-Val-BHAR & - & - & - & 12 & 20 & 36 & 44 & 61 & 82 & 90 & 93 & 95 & 100 \\
\hline Ala-Phe-BHAR & - & - & - & 11 & 19 & 34 & 41 & 48 & - & 56 & - & 85 & 99 \\
\hline
\end{tabular}

Table 3. The approximate time (h) necessary for the complete hydrolysis of resin-bound aminoacyl- and dipeptidyl-groups at $130{ }^{\circ} \mathrm{C}$ and $160{ }^{\circ} \mathrm{C}$ in propionic acid: $12 \mathrm{~N} \mathrm{HCl}(1: 1, \mathrm{v} / \mathrm{v})$.

\begin{tabular}{|c|c|c|c|c|c|c|c|c|}
\hline \multirow{3}{*}{$\begin{array}{l}\text { Amino acyl or } \\
\text { dipeptidyl-resin }\end{array}$} & \multicolumn{2}{|c|}{ CMSD } & \multicolumn{2}{|c|}{ PAMR } & \multicolumn{2}{|c|}{ MBHAR } & \multicolumn{2}{|c|}{ BHAR } \\
\hline & $130^{\circ} \mathrm{C}$ & $160^{\circ} \mathrm{C}$ & $130^{\circ} \mathrm{C}$ & $160^{\circ} \mathrm{C}$ & $130^{\circ} \mathrm{C}$ & $160^{\circ} \mathrm{C}$ & $130^{\circ} \mathrm{C}$ & $160^{\circ} \mathrm{C}$ \\
\hline & \multicolumn{8}{|c|}{ Time (h) } \\
\hline Gly-R & 15 & 6 & 20 & 10 & 20 & 10 & 30 & 15 \\
\hline Val-R & 20 & 10 & 25 & 15 & 25 & 15 & 70 & 25 \\
\hline Phe-R & 40 & 15 & 50 & 18 & 50 & 18 & 100 & 30 \\
\hline Ala-Gly-R & 10 & 0.5 & 15 & 4 & 15 & 4 & 20 & 5 \\
\hline Ala-Val-R & 15 & 4 & 20 & 6 & 20 & 7 & 60 & 20 \\
\hline Ala-Phe-R & 20 & 7 & 30 & 10 & 30 & 12 & 80 & 25 \\
\hline
\end{tabular}

resin and its pendant group and also on the hydrolysis temperature. Therefore, it is important to always be aware of the acid-sensitivity of each class of amino acid to hydrolysis conditions for any quantitative amino acid or peptide content- determination in resin. Much longer reaction times than initially reported in the field of peptide chemistry are needed, depending on the resin sample.

The present report points to the need for further research with alternative protocols which might allow a reduction in resin hydrolysis times. Cleavage experiments with other hydrolytic systems, such as potassium carbonate in the presence of a phase transfer reagent and ultrasound ${ }^{17}$, triethanolamine, dimethylformamide and aqueous sodium hydroxide ${ }^{18}$, methanosulfonic acid/propionic acid/water ${ }^{19}$, and even the application of the microwave approach $^{20}$, are currently been underway in our laboratory.

\section{Acknowledgments}

We are indebted to Prof. Antonio C. M. Paiva for valuable comments and suggestions. Financial support from FAPESP and CNPq is gratefully acknowledged.

\section{References}

1. Barany, G.; Merrifield, B.R. In The Peptides Analysis, Synthesis, Biology; Vol. 2; Gross, E.; Meienhofer, J., Eds.; Academic Press; New York,1980, p 1.

2. Stewart, J.M.; Young, J. In Solid Phase Peptide Synthesis, Pierce Chemical Co.; Rockford, Illinois, 1984.

3. Fields, G.B.; Noble, R.L. Int. J. Peptide Protein Res. 1990, 35,161 . 
4. Atherton, E.; Sheppard, R.C. In Solid Phase Peptide Synthesis: A Practical Approach, IRL Press, Oxford, 1989.

5. Scotchler, J.; Lozier, R.; Robinson, A.B. J. Org. Chem. 1970, 35, 3151.

6. Westall, F.C., Scotchler, J.; Robinson, A.B. J. Org. Chem. 1972, 37, 3363.

7. Westall, F.C.; Hesser, H. Anal. Biochem. 1974, 61, 610.

8. Mitchell, A.R.; Erickson, B.W.; Ryabtsev, M.N.; Hodges, R.S.; Merrifield, R.B. J. Amer. Chem. Soc. 1976, 98, 7357.

9. Piettà, P.G.; Cavallo, P.F.; Takahashi, K.; Marshall, G.R. J. Org. Chem. 1974, 39, 44.

10. Matsueda, G.R.; Stewart, J.M.; Peptides 1981, 2, 45.

11. Kaiser, E.; Colescott, R.L.; Bossinger, C.D.; Cook, P.I. Anal. Biochem. 1970, 34, 595.
12. Stewart, J.M. J. Macromol. Sci. Chem. 1976, 10, 259.

13. Wang, S.S.; Wang, B.S.H.; Hughes, J.L.; Leopold, E.J.; Wu, C.R.; Tam, J.P. Int. J. Peptide Protein Res. 1992, 40, 344.

14. Mitchell, A.R.; Kent, S.B.H.; Engelhard, M.; Merrifield, R.B. J. Org. Chem. 1978, 43, 2845.

15. Orlowsky, R.C.; Walter, R.; Winkler, D. J. Org. Chem. 1976, 41, 3701.

16. Marchetto, R.; Etchegaray, A.; Nakaie, C.R. J. Braz. Chem. Soc. 1992, 3 (1, 2), 30.

17. Anwer, M.K.; Spatola, A.F. Tetrahedron Lett. 1992 , $33,3121$.

18. Anuradha, M.V.; Ravindranath, B. Tetrahedron 1995, 51, 5675.

19. Davis, J.H.; Clare, D.M.; Hodges, R.S.; Bloom, M. Biochemistry 1983, 22, 5298.

20. Chien, S.T.; Chiou, S.H.; Chu, Y.H.; Wang, K.T. Int. J. Peptide Protein Res. 1987, 30, 572.

FAPESP helped in meeting the publication costs of this article 